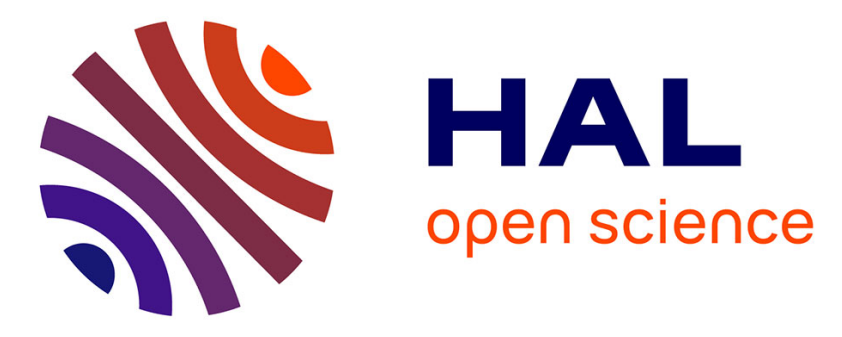

\title{
Treatment of polymer surfaces by low pressure microwave plasmas
}

\author{
B. Mutel, O. Dessaux, P. Goudmand, J. Grimblot, Alexandra Carpentier, S. \\ Szarzynski
}

\section{- To cite this version:}

B. Mutel, O. Dessaux, P. Goudmand, J. Grimblot, Alexandra Carpentier, et al.. Treatment of polymer surfaces by low pressure microwave plasmas. Revue de Physique Appliquée, 1988, 23 (7), pp.12531255. 10.1051/rphysap:019880023070125300 . jpa-00245938

\section{HAL Id: jpa-00245938 https://hal.science/jpa-00245938}

Submitted on 1 Jan 1988

HAL is a multi-disciplinary open access archive for the deposit and dissemination of scientific research documents, whether they are published or not. The documents may come from teaching and research institutions in France or abroad, or from public or private research centers.
L'archive ouverte pluridisciplinaire HAL, est destinée au dépôt et à la diffusion de documents scientifiques de niveau recherche, publiés ou non, émanant des établissements d'enseignement et de recherche français ou étrangers, des laboratoires publics ou privés. 
Classification

Physics Abstracts

$82.65-52.75$

\title{
Treatment of polymer surfaces by low pressure microwave plasmas
}

\author{
B. Mutel $\left({ }^{1}\right)$, O. Dessaux $\left({ }^{1}\right)$, P. Goudmand $\left({ }^{1}\right)$, J. Grimblot $\left({ }^{2}\right)$, A. Carpentier $\left({ }^{3}\right)$ \\ and S. Szarzynski $\left({ }^{4}\right)$ \\ (') L.E.F.E.M.O., Université des Sciences et Techniques de Lille, Flandres Artois, 59655 Villeneuve d'Ascq \\ Cedex, France \\ (2) Laboratoire de catalyse hétérogène et homogène, UA CNRS 402, Université des Sciences et Techniques \\ de Lille, Flandres Artois, 59655 Villeneuve d'Ascq Cedex, France \\ $\left.{ }^{3}\right)$ Electricité de France, Ferme Dupire, 59650 Villeneuve d'Ascq, France \\ (4) Société RIFA SA, 64 boulevard de la Liane, 62206 Boulogne s/Mer, France
}

(Reçu le 19 octobre 1987, accepté le 8 décembre 1987)

\begin{abstract}
Résumé. - Un plasma froid d'azote (dopé ou non par des dérivés fluorés) produit par une décharge microonde sous pression réduite améliore la mouillabilité et les propriétés adhésives du polypropylène. Ce procédé a pour objectif la création de propriétés adhésives entre une résine époxyde et des surfaces de polypropylène en vue de la fabrication de composants électroniques. Il doit remplacer un procédé industriel onéreux et polluant nécessitant de hautes températures pendant environ sept heures. Le coût énergétique est divisé par 700 . La surface du polypropylène a été étudiée par microscopie électronique et par XPS. Après le traitement par plasma, de l'azote est détecté dans les premières couches superficielles du matériau avec une stœchiométrie atomique apparente $\mathrm{N} / \mathrm{C}$ voisine de 0,22 .
\end{abstract}

\begin{abstract}
Improved wettability and adhesion are obtained for polypropylene after brief exposure to a low pressure microwave cold nitrogen plasma which optionally may contain fluorine compounds. This process is used to create adhesion of epoxy resins on polypropylene surfaces for the fabrication of electronic components. It has to take the place of a very expensive and polluting industrial treatment requiring high temperatures for about seven hours. Energy cost is divided by 700 . The surfaces of polypropylene have been examined by means of electronic microscopy and XPS. Incorporation of nitrogen in the first surface layers is observed after the plasma treatment with an apparent N/C atomic stoichiometry of about 0.22 .
\end{abstract}

\section{Introduction.}

A low temperature plasma process is used to modify the physical and chemical structure of polymer surfaces leading to an increase of adhesion towards other substances. From an industrial point of view, the problem of wettability of plastic surfaces is very attractive because it involves many applications such as painting, inking, adhesion... In comparison with the chemical process used at present in industry, plasma technology is simple, clean and cheap.

The aim of this work is a rational use of a nitrogen postdischarge plasma (with or without fluorine additive) produced by a low pressure microwave discharge, to increase the wettability of polypropylene surfaces in order to improve the adhesion of epoxy resin used to protect electronic components in their boxes. At present time, this process which is carried out by a chemical method is very expensive both in energy and cost.

\section{Experimental.}

2.1 Plasma DeVice. - A schematic diagram of the experimental set up is shown figure 1 . The gaseous flow, created by continuous pumping, is excited in an electrodeless discharge by means of a microwave generator GHF 1211C Thomson-CSF which delivers at a fixed frequency $(2450 \mathrm{MHz})$ for variable powers $(0-1500 \mathrm{~W})$. The discharge cavity (Fig. 2) conceived and improved in the laboratory is built from a 


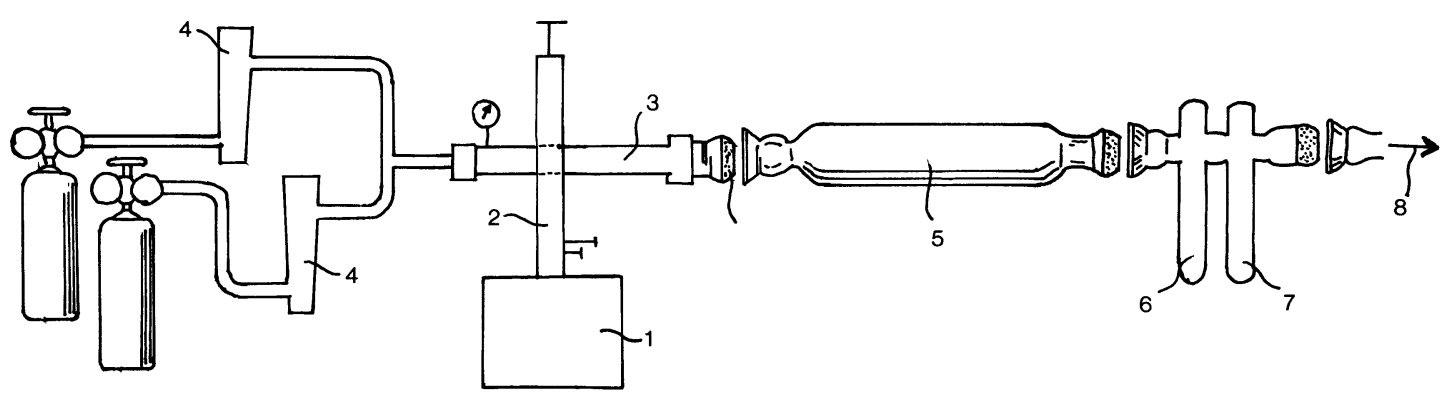

Fig. 1. - Experimental device : (1) Microwave generator ; (2) Resonant cavity ; (3) Quartz tube ; (4) Mass flow controller; (5) Pyrex reactor ; (6) Trap with copper ; (7) Trap with liquid nitrogen ; (8) Pump.

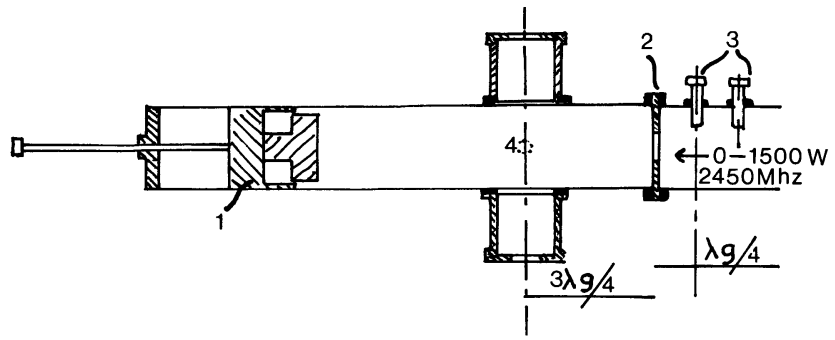

Fig. 2. - Resonant cavity : (1) Piston ; (2) Iris ; (3) Set screw ; (4) Compressed air.

waveguide RG 112/U [1]. The discharge is produced in a quartz tube ( $15 \mathrm{~mm}$ inner diameter) which is coupled to a cylindrical pyrex reactor whose capacity is 2 litres. This reactor contains pieces which are to be treated.

Plasma gases are either commercial nitrogen Air Liquide $\mathrm{R}$ quality or $\mathrm{N}_{2}-\mathrm{CF}_{4}$ or $\mathrm{N}_{2}-\mathrm{NF}_{3}$ mixtures whose percentage in fluorine compound does not exceed $5 \%$ in volume. Gas flows are measured with a RDM-280 Alphagaz mass flow controller. Pressure in the reactor is measured by a Pirani gauge.

Two traps containing respectively copper wool and liquid nitrogen are placed downstream from the reactor.

2.2 Characterization techniques. - The XPS measurements were obtained with a Leybold HS-10 spectrometer equipped with an aluminium anode. After the plasma treatment, the samples were transferred in air before being introduced into the spectrometer. During analysis, the vacuum was better than $10^{-8}$ torr.

Studies by electronic microscopy have been carried out with a scanning device J.E.O.L. model 100-B. Surfaces of polypropylene have been studied with magnification from 8000 to 20000 .

\section{Results and discussion.}

3.1 SAMPLE PREPARATION. - The resonant cavity used enabled us to obtain, in a dynamic flow, and out of the discharge zone, a low temperature plasma. The main chemical species present in a cold nitrogen plasma are atomic nitrogen in its ground state $\mathbf{N}\left({ }^{4} \mathrm{~S}\right)$, vibrationally excited nitrogen molecules in the ground electronic state $\mathrm{N}_{2}\left(\mathrm{X}^{1} \Sigma_{\mathrm{g}}^{+}\right)_{\mathrm{v}}$ and electronically excited nitrogen molecules $\mathrm{N}_{2}\left(\mathrm{~A}^{3} \Sigma_{\mathrm{u}}^{+}\right)$. Ion and free electron concentrations are very low. Kinetics of nitrogen atom recombination $[1,2]$ is such that a very high volume plasma can be obtained. With the reactor used at present, it is possible to treat simultaneously fourteen multiboxes $\left(144.6 \mathrm{~cm}^{3}\right.$ each). After treatment, these multiboxes are filled up with an epoxy resin whose polymerization is accomplished thermally. Fundamental studies on climatic and mechanical resistance are carried out to test whether treated surfaces are able to withstand fast temperature variation or a corrosive atmosphere similar to conditions which can happen during storage or transport. Electronic components produced from these treated boxes are also tested to determine whether they are able to withstand heat and mechanical shocks involved in space and aircraft industries. These tests are consistent with CECC 30000 and 30400 norms. Excellent results are obtained with a total pressure equal to 20 torr and a microwave power transmitted to the plasma equal to $80 \mathrm{~W}$. With a nitrogen plasma, the optimum duration for an efficient treatment is 3 min. With a nitrogenfluorine compound (4\%) mixture, the optimum duration for the treatment is, with the same parameters, equal to $1 \mathrm{~min}$. In the latter case, consumption of energy, in comparison with the industrial process requiring high temperatures during about seven hours, is divided by 700 . Economic cost is divided by 4 . Adhesive qualities of the treated surface remained excellent even after accelerated aging (before or after filling).

3.2 SPECTROSCOPIC STUDY. - In order to explain the mechanisms of the adhesive process and improved wettability, the polypropylene surface has been studied by optical and spectroscopic methods before and after plasma treatment. 
3.2.1 Electronic microscopy. - The low wettability of polypropylene before treatment is explained by the existence of an irregular crackles net on the surface. After treatment by plasma $\left(\mathrm{N}_{2}, \mathrm{~N}_{2}-\mathrm{CF}_{4}\right.$ or $\mathrm{N}_{2}-\mathrm{NF}_{3}$ ) the crackles density by surface unit does not increase, but the depth of each crackle increases. The absolute value of this depth has not been measured. It appears that the part of active species of the plasma is to dig crackles already present in the untreated materiel.

3.2.2 X-Ray photoelectron spectroscopy. - By XPS, a strong chemical modification of the polypropylene surface is observed after treatment by plasma (Fig. 3). The unique $\mathrm{C}_{1 \mathrm{~s}}$ peak located at $285 \mathrm{eV}$ in the untreated surface is transformed after treatment by the nitrogen plasma. In addition to the peak at $285 \mathrm{eV}$, a broad band between 286.8 to $288.6 \mathrm{eV}$ appears. In addition, $\mathrm{a} \mathrm{N}_{1 \mathrm{~s}}$ peak appears at $400.0 \mathrm{eV}$. On the other hand, no significant modification of the $\mathrm{O}_{1 \mathrm{~s}}$ peak located at $532 \mathrm{eV}$ is noticed. This oxygen originates from contamination by air, and the contribution of traces present in the plasma gas can be neglected. These results suggest formation of $-\mathrm{C} \equiv \mathrm{N}$ bonds on the polypropylene surface, but the presence of $=\mathrm{C}=\mathrm{O}$ groups is not excluded [4].

When the sample is treated by a nitrogen-fluorine compound mixture plasma, an important fixation of
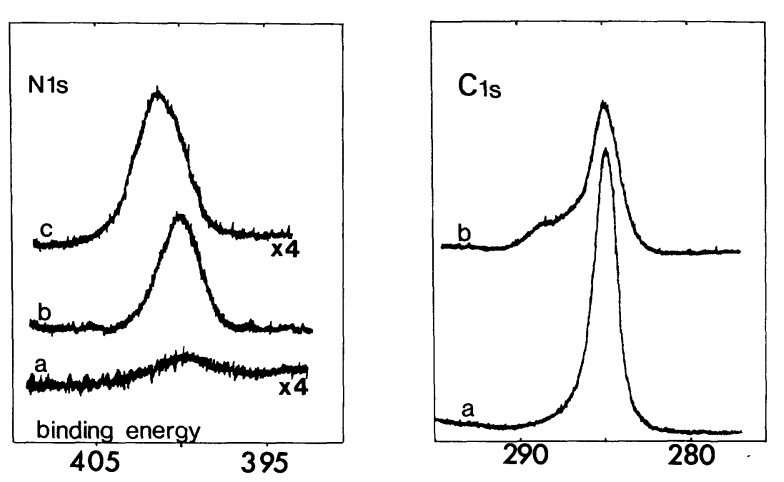

Fig. 3. $-\mathrm{N}_{1 \mathrm{~s}}$ and $\mathrm{C}_{1 \mathrm{~s}}$ photoelectron spectra (binding energy in $\mathrm{eV}$ ): (a) untreated polypropylene ; (b) polypropylene treated with $\mathrm{N}_{2}$ plasma; (c) polypropylene treated with $\mathrm{N}_{2}$-fluorine compound (4\%) mixture plasma. fluorine is observed. The nature of this fixed species is not elucidated yet and is the object of present research.

After treatment, the $\mathrm{N} / \mathrm{C}$ ratio is about 0.22 . To a first approximation it is possible to evaluate the depth of treatment to 0.25 to $0.5 \mathrm{~nm}$. $\mathrm{A}-\mathrm{C} \equiv \mathrm{N}$ (and $\mathrm{a}>\mathrm{C}=\mathrm{O}$ ) bond may occur in crosslinking resin mechanism according to<smiles>CC#[N+]C(C)=C(C)CCC1=NC(C)=C1C</smiles>

A comparison of experimental results obtained with the two methods (electronic microscopy and XPS) leads us to suppose that nitrogen fixation is located around the crackles. When fluorine compounds are present in the plasma gas, a grafting mechanism is added to the previous one and enhances adhesive properties.

\section{Conclusion.}

Microwave energy enables us to obtain a plasma which is efficient for the surface treatment and which offers an important volume in relation to power delivered by generator. Treated surfaces allow adhesion of epoxy resins on plastic material whether charged or not, and the adhesion quality satisfies the standards of electronic components industries. Short treatment duration leads to energy reduction and economic improvement in comparison with industrial processes : energy cost is divided by 700 . These economical results combined with excellent electronic quality of produced components have lead to the realization of a pilot factory [3] to treat simultaneously eight hundred multiboxes (capacity 125 litres). From now on, the industrial installation composed of two five hundred litres reactors is scheduled by RIFA SA to replace chemical process.

From a fundamental point of view, the presence of $-\mathrm{C} \equiv \mathrm{N}$ (and possibly $>\mathrm{C}=\mathrm{O}$ ) bonds occurring in crosslinking resin mechanism is shown as well as a grafting process due to fluorine compounds added to the plasma gas.

References

[1] Mutel, B., Thèse d'Etat n 704 (Lille) 1986.

[2] Dessaux, O., Goudmand, P., Mutel, B., J. Quant. Spectros. Radiat. Transfer 29 (1983) $49 ; 30$ (1983) 137 ; 30 (1983) 31.
[3] Dessaux, O., Mutel, B., Szarzynski, S., Brevet I.N.P.I., n' 8707733 (1987).

[4] Dilks, A., Electron Spectroscopy: Theory Techniques and Applications, Eds. Brundle C. R. and Baker A. D., 4 (1981) 277. 